\title{
Modelling of Electric Grid to Enhance Generated Power Evacuation
}

\author{
Donald Eloebhose \\ Dept. Electrical/Electronic Engineering, \\ University of Port Harcourt, \\ Rivers State, Nigeria
}

\author{
Nelson Ogbogu \\ Dept. Electrical/Electronic Engineering, \\ University of Port Harcourt, \\ Rivers State, Nigeria
}

\begin{abstract}
The study of evacuation of power from the power plants in Rivers State Nigeria, connecting to the 330kV transmission network of the Transmission Company of Nigeria (TCN). The Power World Simulator Educational version was used in the modelling and simulation of the electric power grid. The study of load flow analysis, short circuit, transient and N-1 contingency analysis and their effect on the $330 \mathrm{kV} / 132 \mathrm{kV}$ transmission bus connected to the existing power plants in Rivers State Nigeria namely; Rivers IPP (180MW), Afam III (265.6MW), Afam IV \& V (351.00 MW) and Afam VI G. S (650.00 MW) was carried out. From the short circuit study, it is observed that when a bus is faulted with a 3-phase fault, the three-phase voltages of the system drastically become zero in all the phases. The other buses of the network experience an increase in voltage and all the buses fed have the same effect as the bus under fault, though the effect is felt more on the buses. However, with the introduction of substation splitting at Afam III and ongoing Afam IV substations, the short circuit level will be reduced by $15 \%$; leading to improvement in the overall system stability.
\end{abstract}

Keywords- Power World Simulator, Afam, Short circuit analysis, load flow analysis, contingency analysis, transient analysis.

\section{INTRODUCTION}

The requirement for electric power is constantly increasing, for socio-economic growth in nations of the world, a steady electricity supply is key. The electricity condition in Nigeria currently is poor and nothing to write home about, study shows that, inadequate management of plants and old machines are instrumental to the poor electricity condition in the country [1]. The poor power in Nigeria was largely due to the poor transmission ability of the national grids system and the poor power of the national grid generating capacity of the nation's generating stations among others [2]. Nigeria's major means of generating electricity include thermal, hydro and gas generating stations all distributed over the nation. Nigeria, with its diverse array of renewable and non-renewable energy resources can alleviate the electricity generation crisis. For instance, the country has natural gas reserves of 185 trillion cubic feet, coal reserves of 2.75 billion tons, and crude oil reserves of 35 billion barrels [3]. The above non-renewable energy reserve is sufficient to meet Sub-Saharan Africa's electricity generation demand for many decades [1]. Despite having ample capacity to generate enough energy for its people, Nigeria continues to struggle to meet its citizens' energy needs. Considering the significance of infrastructural facilities and the use of energy in Nigeria, economic development seems to have been sluggish given the absence of power supply.

This is likely to have contributed to the country's slow growth rate, this is most likely a reflection of the country's poor infrastructure growth and why, despite its abundant natural resources, Nigeria is one of the world's poorest economies [4]. The demand for this essential utility is directly proportional to population size. As the population size increases the demand also increases resulting in a corresponding increase in the burden of existing transmission systems, that is, increase in the population size over time will affect the existing transmission lines to be overloaded beyond their designed ratings with a consequent reduction in electrical power transmission quality and in extreme cases; there is total power outage [5]. The key factors behind this situation are the lack of electricity transmission due to the lack of state-of-the-art facilities, the intrinsic deficiency of the current electricity transport system and, of course, the insufficient investment in the power generation sector. This means that the nearly 200 million people in society will find the supply of electricity and the mission of ardor, translating into an energy-deficient society with $121 \mathrm{KWh}$ per capita, 50 times less than the average country in Europe with $10 \%$ of the population of Nigeria [6]. There is a need to build more and more powerful electricity generating stations to meet the growing demand, however, this generated power is ultimately distributed to customers. The electrical power grid network is made up of a generating station, sub-station, transmission and distribution lines.

This study uses Power World Simulator Educational version to analyze load flow, short circuit, transient and N-1 contingency analysis and their effect on the $330 \mathrm{kV} / 132 \mathrm{kV}$ transmission bus connected to the existing generators in Rivers State Nigeria namely; Rivers IPP (180MW), Afam III (265.6MW), Afam IV \& V (351.00 MW) and Afam VI G. S (650.00 MW).

\section{LITERATURE REVIEW}

Power evacuation is a vital feature that enables generated power to be immediately evacuated for transmission and distribution from the generator to the grid. Over the years, power evacuation experiments have been performed primarily for the introduction of new generators into the grid system. Several studies were carried out by [7-12]. Such as the design of $132 \mathrm{kV}$ power evacuation system at Bawktlang substation in Mizoram, India [7]. Optimal analysis of power evacuation of Tiga hydro generator in Kano State [8]; this study did not take into account the fault contribution of the generators to the current network, but carried out comprehensive studies on load flow, Synopsis of maximum control evacuation from the generator to the power grid in Madhya Pradesh. The studies conducted by [7] and [9] do not include all the basic technical details essential for optimizing the smooth evacuation of an 
existing power grid from a new generator. Modelling of an electric Grid for the Evacuation of a new generator carried out by [10]. The introduction of a new generator into a current electricity grid alters the behavior of the power grid into which it is introduced. This study focuses on the performing studies to improve electric power evacuation on an existing power plant. To achieve these serval studies will be performed such as load flow studies [13-17], fault current and the use network bus splitting for reduction of 3-phase fault current [18-19], transient analysis [20-21] and N-1 contingency [22-23]. And research has shown that electricity consumption will continue to increase in Nigeria [24]. Thus, there is need to build more power generating stations and most importantly evacuate all the generated power to the grid system.

In this study, analytical software for the power system was used. This study aims to model an electric power grid of river state generation plants and to certain defined studies on the case study by eliminating one generating plant. Using Power World Software, the impact of the removed generator the entire system was studied.

\section{MATERIALS AND METHOD}

The transmission network of $330 \mathrm{kV} / 132 \mathrm{kV}$ transmission bus connected to the existing generators in Rivers State Nigeria namely; Rivers IPP (180MW), Afam III (265.6MW), Afam IV \& V (351.00 MW) and Afam VI G. S (650.00 MW) was modelled using power world simulation software v21.1

\subsection{Load Flow Modelling}

In this power system evacuation study, buses are considered for modelling see figure 1 .

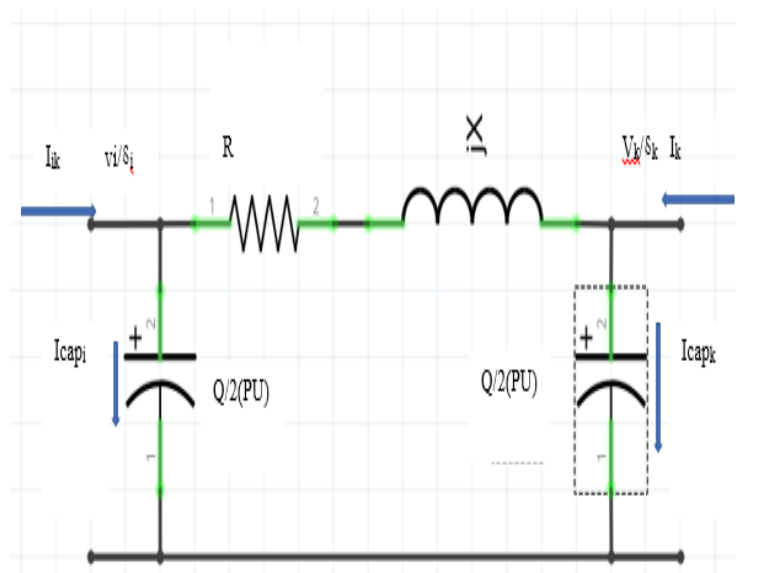

Figure 1: A two-bus power system

$$
\begin{aligned}
& V_{i}=\left|V_{i}\right| e^{j \delta_{i}}=V_{i}\left(\cos \delta_{i}+\mathrm{j} \sin \delta_{i}\right) \\
& Y_{i k}=\left|V_{i k}\right| e^{j \delta_{i k}}=V_{i}\left(\cos \delta_{i k}+\mathrm{j} \sin \delta_{i k}\right)
\end{aligned}
$$

Where,

P means Active Power (MW),

Q means Reactive Power (MVAR),
V means the Magnitude of Bus Voltage $(\mathrm{kV})$,

$\delta$ means Bus Voltage Angle (Degree).

Therefore, Complex power is:

$S_{i}=P_{i}+j Q_{i}=V_{i} I_{i}$

Consider generator and load

$P_{i}=P_{G i}-P_{L i}=\operatorname{Re}\left[V_{i} I_{i}^{*}\right]$

$P_{i}=P_{G i}-P_{L i}=\operatorname{Im}\left[V_{i} I_{i}^{*}\right]$

Then, the expression for bus is:

$I_{\text {bus }}=Y_{\text {bus }} V_{\text {bus }}$

A new arrangement for equations (3), (4) and (5) gives (7), (8) and (9). While the polar form gives (10), (11) and (12)

$$
\begin{aligned}
& I_{b u s}=\frac{P_{i}+j Q_{i}}{V_{i}^{*}}=Y_{i i} V_{i}+\sum_{k=1}^{n} y_{i k} V_{k} \\
& V_{i}=\frac{1}{Y_{i i}}\left[\frac{P_{i}-j Q_{i}}{V_{i}^{*}}-\sum_{k=1}^{n} Y_{i k} V_{k}\right] \\
& P_{i}+j Q_{i}=V_{i} \sum_{k=1}^{n} Y_{i k} V_{k} \\
& P_{i}+j Q_{i}=V_{i} \sum_{k=1}^{n}\left|Y_{i k} V_{k} V_{i}\right| e^{j\left(\delta_{i}-\delta_{k}-\theta_{i k}\right)} \\
& P_{i}=\sum_{k=1}^{n}\left|Y_{i k} V_{k} V_{i}\right| \cos \left(\delta_{i}-\delta_{k}-\theta_{i k}\right) \\
& Q_{i}=\sum_{k=1}^{n}\left|Y_{i k} V_{k} V_{i}\right| \sin \left(\delta_{i}-\delta_{k}-\theta_{i k}\right)
\end{aligned}
$$

Where,

$$
i=1,2, \ldots, n ; \quad i \neq \text { slack bus }
$$

\subsection{Short Circuit Modelling}

For short circuit research, the IEC 60909is applied. In the equations, more is illustrated. Using the symmetrical elements, compute the original short-circuit current. After the rms $I_{k}$ is known, it is possible to measure others.

$I_{k}^{\prime \prime}=\frac{c V_{n}}{\sqrt{3 Z_{k}}}$

$Z_{k}=\left|R_{k}+j X_{R}\right|$

Where,

$\mathrm{Vn}=$ nominal voltage, $\mathrm{C}=$ voltage factor

At the fault spot, $(\mathrm{V}), \mathrm{Z}_{\mathrm{k}}=$ impedance. $\mathrm{R}_{\mathrm{k}}$ and $\mathrm{X}_{\mathrm{k}}=$ resistances and reactance respectively. One can calculate the ratio using the corresponding $\mathrm{R}$ and Positive sequence impedance at the fault site.

$\cdot \frac{X}{R}=\frac{X_{k}}{R_{k}}$

$\mathrm{Ip}=$ peak current given as

Where,

$E_{i}^{\prime}=\left|E_{i}^{\prime}\right| \angle \delta_{i}$ and $\left|Y_{i j}\right|=\left|Y_{i j}\right| \angle \theta_{i j}$ and $Y_{i j}$ is the $\mathrm{ij}^{\text {th }}$

$I_{p}=1.15 \beta X \sqrt{2 I_{k}^{\prime \prime}}$ 
Where $\beta$ is expressed as,

$\beta=1.02 \times 0.9 e^{\frac{3}{X / R}}$

\subsection{Transient Stability Analysis Model}

The analysis of transient stability begins by solving the initial flow of load and initial flow of the bus. About voltages. Before disturbance, the following equation 3.17 computes the machine currents.

$$
\begin{gathered}
I_{i}=\frac{S_{i}^{*}}{V_{i}^{*}} \\
i=1,2, \ldots, m
\end{gathered}
$$

Here, Number of generators, generator terminal voltage, and generator complex power
For the electircal power is computed as

$$
P_{e i}=\sum_{j=1}^{m}\left|E_{i}^{\prime}\right|\left|E_{j}^{\prime}\right|\left|Y_{i j}\right| \cos \left(\theta_{i j}-\delta_{i}+\delta_{j}\right)
$$




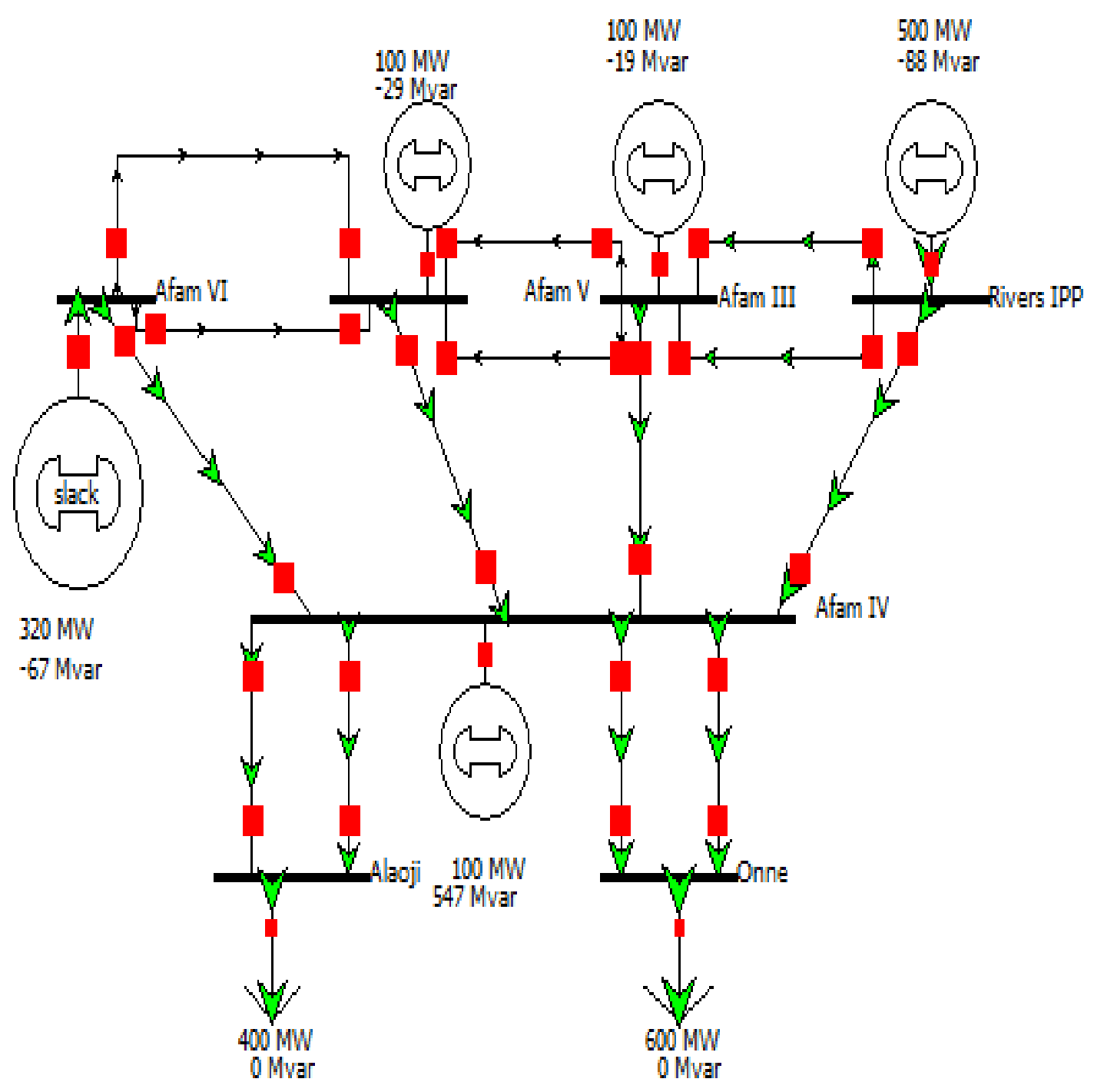

Figure 2. The Power world simulator model of the TCN 330/132 KV Network 


\section{RESULTS AND DISCUSSION}

\subsection{Results of Load Flow Studies}

In addition, the Analysis of power flow in the entire $132 \mathrm{KV}$ of the River State Generators to understudy the voltage profile in the power plant network was studied. In the cases analyzed, Table 1 presents the voltage profile in power plant buses is within reasonable limits (1.0 PU). See illustration

\subsection{The Results of Equipment Loading}

There are no overloaded components in the study case; however, when the system is loaded to 150 , percent of the power generating capability of the entire system, its entire network blacks out due to the network overloading, see Figure 3. In this case, the incorporation of a new generation station will resolve the issue.

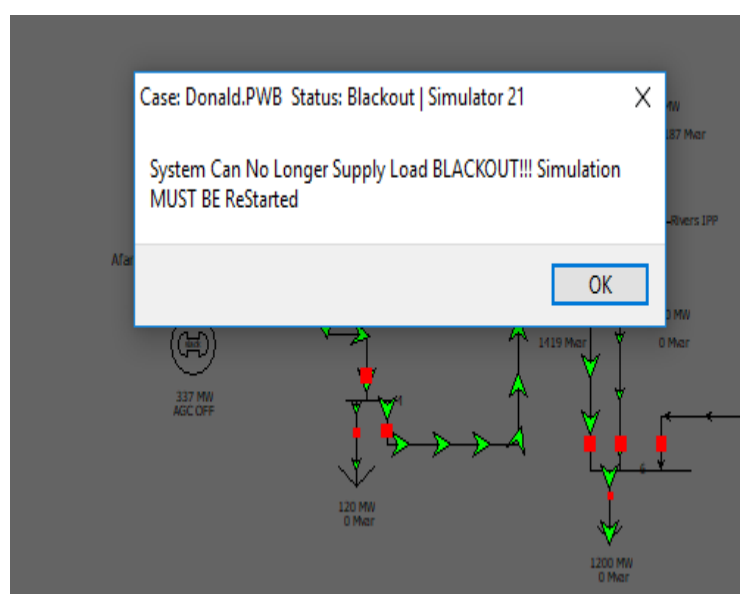

Figure 3: Result of Equipment Loading

\subsection{The Results of Short Circuit Studies}

This work considers 3- phase fault for analysis of short circuit to ascertain fault voltages and at the different current level generator inside the interconnected structure, buses to check Adequacy of Switchgear ratings. This was done by applying a fault of three phase on all the $132 \mathrm{kV}$ bus bars in the system undergoing analysis. When a bus is faulted with a 3-phase fault, the three-phase voltages of the system drastically become zero in all the phases. The other buses of the network experience an increase in voltage and all the buses fed have the same effect as the bus under fault, though the effect is felt more on the buses.
Table 1: Analysis of power flow of the network under study

\begin{tabular}{|c|c|c|c|c|c|c|}
\hline $\begin{array}{l}\text { Num } \\
\text { ber }\end{array}$ & Name & $\begin{array}{l}\mathrm{Ar} \\
\text { ea } \\
\mathrm{Na} \\
\mathrm{me}\end{array}$ & $\begin{array}{l}\text { Nom } \\
\text { KV }\end{array}$ & \begin{tabular}{|l}
$\mathrm{P}$ \\
$\mathrm{U}$ \\
$\mathrm{Vo}$ \\
lt
\end{tabular} & $\begin{array}{l}\text { Volt } \\
(\mathrm{kV})\end{array}$ & $\begin{array}{l}\text { Angle } \\
\text { (Deg) }\end{array}$ \\
\hline 1 & $\begin{array}{l}\text { Afam } \\
\text { VI }\end{array}$ & 1 & $\begin{array}{l}132.0 \\
0\end{array}$ & $\begin{array}{l}1.000 \\
0\end{array}$ & $\begin{array}{l}132.0 \\
0\end{array}$ & 0.00 \\
\hline 2 & $\begin{array}{l}\text { Afam } \\
\text { V }\end{array}$ & 1 & $\begin{array}{l}132.0 \\
0\end{array}$ & $\begin{array}{l}1.000 \\
0\end{array}$ & $\begin{array}{l}132.0 \\
0\end{array}$ & -4.15 \\
\hline 3 & $\begin{array}{l}\text { Afam } \\
\text { III }\end{array}$ & 1 & $\begin{array}{l}132.0 \\
0\end{array}$ & $\begin{array}{l}1.000 \\
0\end{array}$ & $\begin{array}{l}132.0 \\
0\end{array}$ & -4.20 \\
\hline 4 & $\begin{array}{l}\text { Rivers } \\
\text { IPP }\end{array}$ & 1 & $\begin{array}{l}132.0 \\
0\end{array}$ & $\begin{array}{l}1.000 \\
0\end{array}$ & $\begin{array}{l}132.0 \\
0\end{array}$ & -0.15 \\
\hline 5 & $\begin{array}{l}\text { Afam } \\
\text { IV }\end{array}$ & 1 & $\begin{array}{l}132.0 \\
0\end{array}$ & $\begin{array}{l}0.775 \\
92\end{array}$ & $\begin{array}{l}102.4 \\
21\end{array}$ & -16.5 \\
\hline 6 & Alaoji & 1 & $\begin{array}{l}132.0 \\
0\end{array}$ & $\begin{array}{l}0.684 \\
03\end{array}$ & $\begin{array}{l}90.29 \\
3\end{array}$ & -34.11 \\
\hline 7 & Onne & 1 & $\begin{array}{l}132.0 \\
0\end{array}$ & $\begin{array}{l}0.579 \\
77\end{array}$ & $\begin{array}{l}76.53 \\
0\end{array}$ & -46.30 \\
\hline
\end{tabular}

Table 2: 3-phase Fault Afam VI

\begin{tabular}{|l|l|l|l|l|l|}
\hline $\begin{array}{l}\text { Num } \\
\text { ber }\end{array}$ & Name & $\begin{array}{l}\text { Phase } \\
\text { Volt A }\end{array}$ & $\begin{array}{l}\text { Phase } \\
\text { Volt B }\end{array}$ & \multicolumn{2}{|l|}{$\begin{array}{l}\text { Phase } \\
\text { Volt C }\end{array}$} \\
\hline $\mathbf{1}$ & $\begin{array}{l}\text { Afam } \\
\text { VI }\end{array}$ & 0 & 0 & 0 & \\
\hline $\mathbf{2}$ & $\begin{array}{l}\text { Afam } \\
\text { V }\end{array}$ & 0.1773 & 0.1773 & 0.1773 & \\
\hline $\mathbf{3}$ & $\begin{array}{l}\text { Afam } \\
\text { III }\end{array}$ & 0.27426 & 0.27426 & $\begin{array}{l}0.2742 \\
6\end{array}$ \\
\hline $\mathbf{4}$ & $\begin{array}{l}\text { Rivers } \\
\text { IPP }\end{array}$ & 0.34973 & 0.34973 & $\begin{array}{l}0.3497 \\
3\end{array}$ \\
\hline $\mathbf{5}$ & $\begin{array}{l}\text { Afam } \\
\text { IV }\end{array}$ & 0.271 & 0.271 & 0.271 \\
\hline $\mathbf{6}$ & $\begin{array}{l}\text { Alaoji } \\
\mathbf{n}\end{array}$ & 0.25664 & 0.25664 & $\begin{array}{l}0.2566 \\
4\end{array}$ \\
\hline $\mathbf{7}$ & Onne & 0.24405 & 0.24405 & 0.2440 \\
\end{tabular}




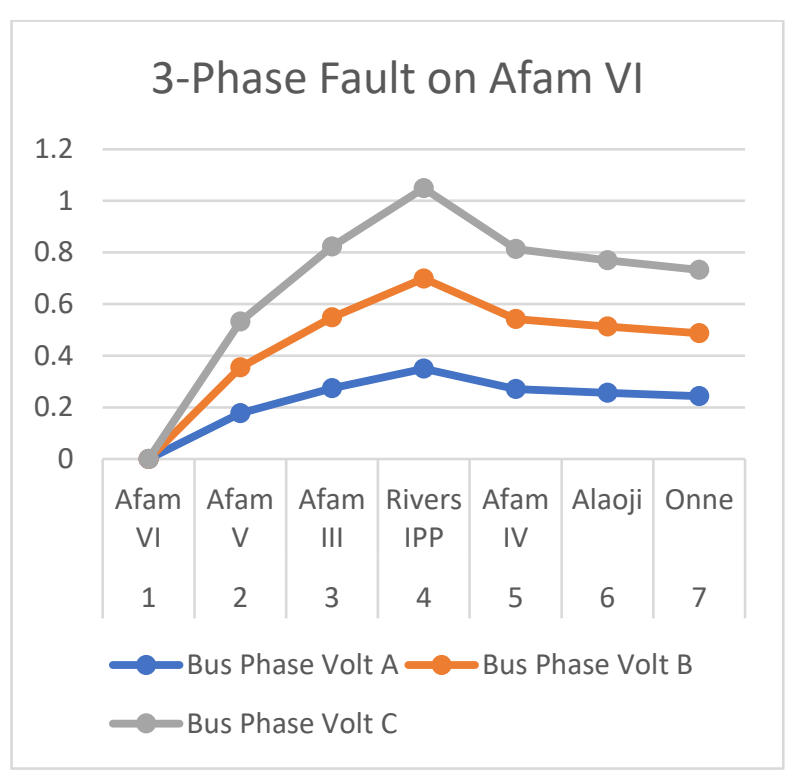

Figure 4: 3-Phase Fault on Afam VI

Table 3: 3-Phase Fault on Afam V

\begin{tabular}{|l|l|l|l|l|}
\hline $\begin{array}{l}\text { Numb } \\
\text { er }\end{array}$ & Name & $\begin{array}{l}\text { Phase } \\
\text { Volt A }\end{array}$ & $\begin{array}{l}\text { Phase } \\
\text { Volt B }\end{array}$ & $\begin{array}{l}\text { Phase } \\
\text { Volt C }\end{array}$ \\
\hline $\mathbf{1}$ & $\begin{array}{l}\text { Afam } \\
\text { VI }\end{array}$ & 0.12944 & 0.12944 & 0.12944 \\
\hline $\mathbf{2}$ & Afam V & 0 & 0 & 0 \\
\hline $\mathbf{3}$ & $\begin{array}{l}\text { Afam } \\
\text { III }\end{array}$ & 0.15845 & 0.15845 & 0.15845 \\
\hline $\mathbf{4}$ & $\begin{array}{l}\text { Rivers } \\
\text { IPP }\end{array}$ & 0.26558 & 0.26558 & 0.26558 \\
\hline $\mathbf{5}$ & $\begin{array}{l}\text { Afam } \\
\text { IV }\end{array}$ & 0.20927 & 0.20927 & 0.20927 \\
\hline $\mathbf{6}$ & Alaoji & 0.19818 & 0.19818 & 0.19818 \\
\hline $\mathbf{7}$ & Onne & 0.18846 & 0.18846 & 0.18846 \\
\hline
\end{tabular}

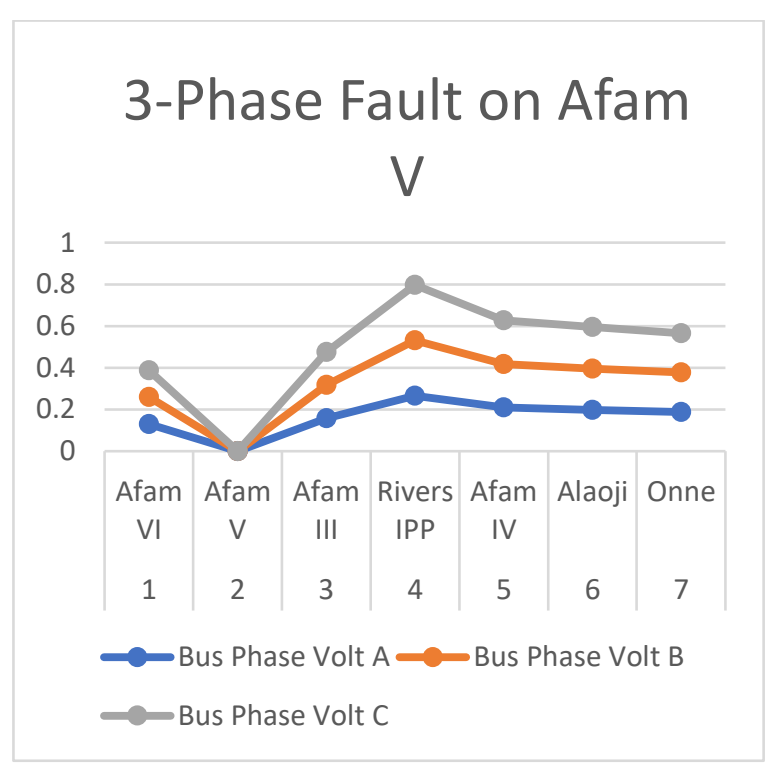

Figure 5: 3-Phase Fault on Afam V

Table 4: 3-Phase Fault on Afam III

\begin{tabular}{|l|l|l|l|l|}
\hline $\begin{array}{l}\text { Numb } \\
\text { er }\end{array}$ & Name & $\begin{array}{l}\text { Phase } \\
\text { Volt A }\end{array}$ & $\begin{array}{l}\text { Phase } \\
\text { Volt B }\end{array}$ & $\begin{array}{l}\text { Phase } \\
\text { Volt C }\end{array}$ \\
\hline $\mathbf{1}$ & $\begin{array}{l}\text { Afam } \\
\text { VI }\end{array}$ & 0.21533 & 0.21533 & 0.21533 \\
\hline $\mathbf{2}$ & Afam V & 0.14004 & 0.14004 & 0.14004 \\
\hline $\mathbf{3}$ & $\begin{array}{l}\text { Afam } \\
\text { III }\end{array}$ & 0 & 0 & 0 \\
\hline $\mathbf{4}$ & $\begin{array}{l}\text { Rivers } \\
\text { IPP }\end{array}$ & 0.1615 & 0.1615 & 0.1615 \\
\hline $\mathbf{5}$ & $\begin{array}{l}\text { Afam } \\
\text { IV }\end{array}$ & 0.20532 & 0.20532 & 0.20532 \\
\hline $\mathbf{6}$ & Alaoji & 0.19444 & 0.19444 & 0.19444 \\
\hline
\end{tabular}




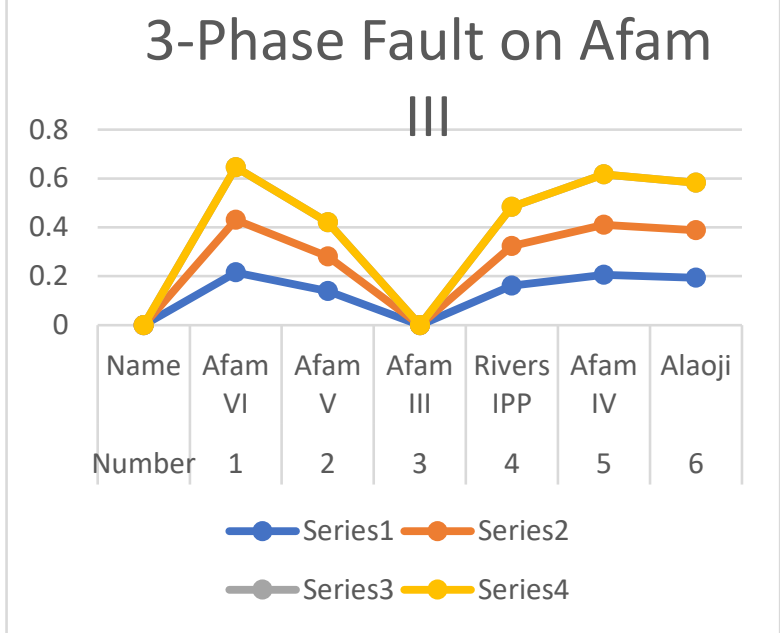

Figure 6: 3-Phase Fault on Afam III

Table 5: 3-Phase Fault on Rivers IPP

\begin{tabular}{|l|l|l|l|l|}
\hline Number & Name & $\begin{array}{l}\text { Phase } \\
\text { Volt A }\end{array}$ & $\begin{array}{l}\text { Phase } \\
\text { Volt B }\end{array}$ & $\begin{array}{l}\text { Phase } \\
\text { Volt C }\end{array}$ \\
\hline $\mathbf{1}$ & Afam VI & 0.28949 & 0.28949 & 0.28949 \\
\hline $\mathbf{2}$ & Afam V & 0.24397 & 0.24397 & 0.24397 \\
\hline $\mathbf{3}$ & Afam III & 0.16408 & 0.16408 & 0.16408 \\
\hline $\mathbf{4}$ & $\begin{array}{l}\text { Rivers } \\
\text { IPP }\end{array}$ & 0 & 0 & 0 \\
\hline $\mathbf{5}$ & Afam IV & 0.26155 & 0.26155 & 0.26155 \\
\hline $\mathbf{6}$ & Alaoji & 0.24769 & 0.24769 & 0.24769 \\
\hline $\mathbf{7}$ & Onne & 0.23554 & 0.23554 & 0.23554 \\
\hline
\end{tabular}

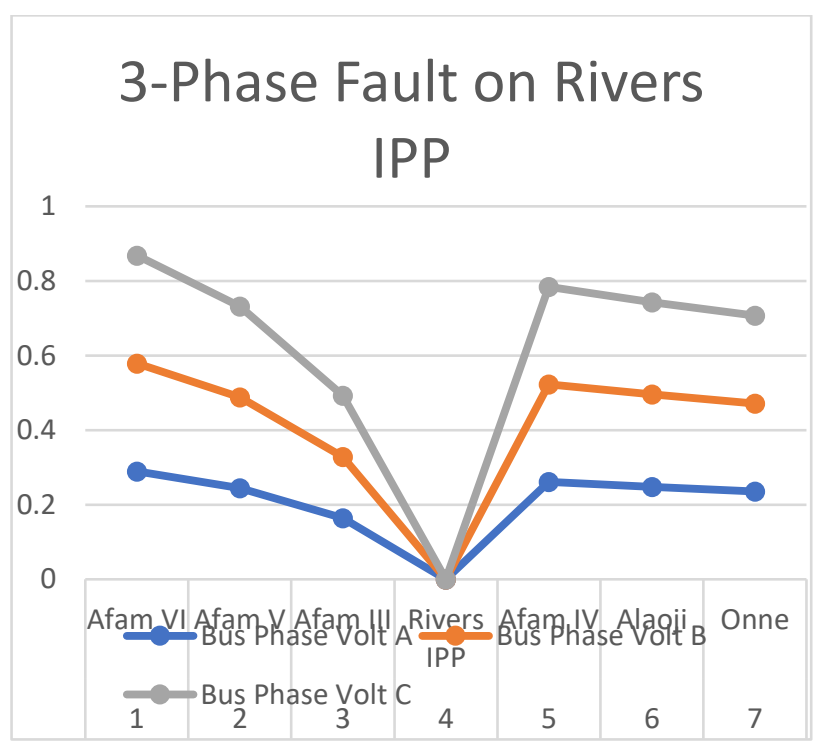

Figure 7: 3-Phase Fault on Rivers IPP
Table 6: 3-phase Fault on Afam IV

\begin{tabular}{|l|l|l|l|l|}
\hline $\begin{array}{l}\text { Numb } \\
\text { er }\end{array}$ & Name & $\begin{array}{l}\text { Phase } \\
\text { Volt A }\end{array}$ & $\begin{array}{l}\text { Phase } \\
\text { Volt B }\end{array}$ & $\begin{array}{l}\text { Phase } \\
\text { Volt C }\end{array}$ \\
\hline $\mathbf{1}$ & $\begin{array}{l}\text { Afam } \\
\text { VI }\end{array}$ & 0.19568 & 0.19568 & 0.19568 \\
\hline $\mathbf{2}$ & Afam V & 0.16803 & 0.16803 & 0.16803 \\
\hline $\mathbf{3}$ & $\begin{array}{l}\text { Afam } \\
\text { III }\end{array}$ & 0.18377 & 0.18377 & 0.18377 \\
\hline $\mathbf{4}$ & $\begin{array}{l}\text { Rivers } \\
\text { IPP }\end{array}$ & 0.25264 & 0.25264 & 0.25264 \\
\hline $\mathbf{5}$ & $\begin{array}{l}\text { Afam } \\
\text { IV }\end{array}$ & 0 & 0 & 0 \\
\hline $\mathbf{6}$ & Alaoji & 0 & 0 & 0 \\
\hline $\mathbf{7}$ & Onne & 0 & 0 & 0 \\
\hline
\end{tabular}

\section{3-Phase Fault on Afam}

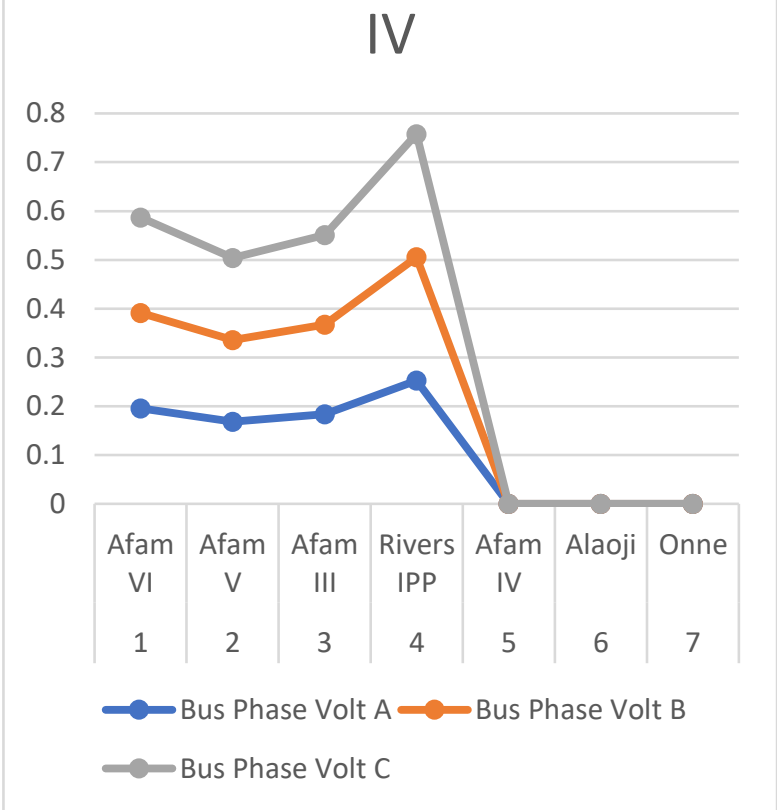

Figure 8: 3-Phase Fault on Afam IV

\subsection{The Results of Reduction of Fault Current through Substation Splitting.}

Substation splitting was performed in Afam V and $132 \mathrm{kV}$ generators were opened in Afam III in attempt to lessen the short circuit current throughout the system, and new fault current levels in the network were identified throughout the system buses. The percentage reduction of the default current is seen in Table 7 and Figure 9 owing to the removed generator. 
Table 7 Fault Current when Afam V and III are shutdown

\begin{tabular}{|l|l|l|l|l|}
\hline $\begin{array}{l}\text { Nu } \\
\text { mbe } \\
\mathbf{r}\end{array}$ & $\begin{array}{l}\text { Nam } \\
\text { e }\end{array}$ & $\begin{array}{l}\text { Fault } \\
\text { Current } \\
\text { Amps }\end{array}$ & $\begin{array}{l}\text { Current } \\
\text { before Fault } \\
\text { Amps }\end{array}$ & $\begin{array}{l}\text { Current } \\
\text { after } \\
\text { Split }\end{array}$ \\
\hline $\mathbf{1}$ & $\begin{array}{l}\text { Afa } \\
\text { m V }\end{array}$ & 4095 & 4202 & 4088 \\
\hline $\mathbf{2}$ & $\begin{array}{l}\text { Afa } \\
\text { m IV }\end{array}$ & 4535 & 4202 & 3947 \\
\hline $\mathbf{3}$ & $\begin{array}{l}\text { Afa } \\
\text { m III }\end{array}$ & 4535 & 4202 & 4088 \\
\hline $\mathbf{4}$ & $\begin{array}{l}\text { Afa } \\
\text { m VI }\end{array}$ & 5378 & 4202 & 4980 \\
\hline $\mathbf{5}$ & $\begin{array}{l}\text { River } \\
\text { s IPP }\end{array}$ & 4202 & 4202 & 3947 \\
\hline
\end{tabular}

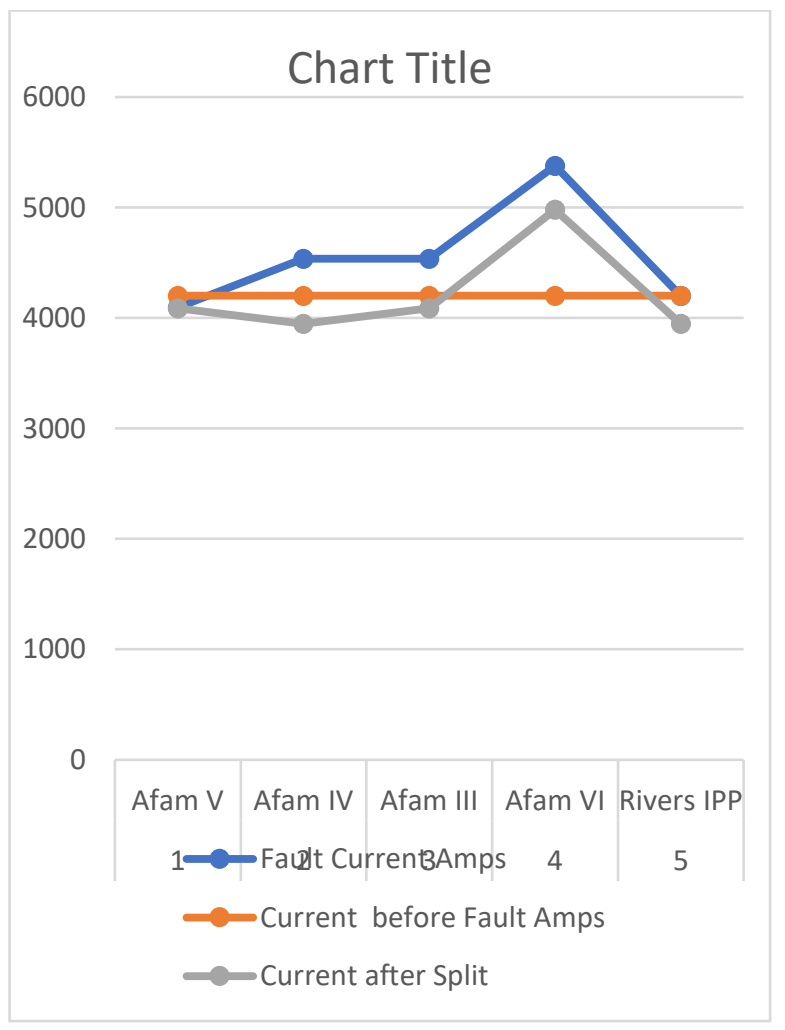

Figure 9: Fault current when Afam III and V are shutdown

\subsection{The Results of Transient Stability Studies}

As the Afam IV bus $132 \mathrm{kV}$ faulted with a three phase faults for $150 \mathrm{~ms}$, this is simulated by the insertion of a shunt with 0.00001 p.u reactance at the power station. To monitor the effectiveness of the multiple generators in order to clear the fault duration, the shunt is originally turned out, then turned at 2.0 seconds following the study begins, and cleared after 10 iterations.

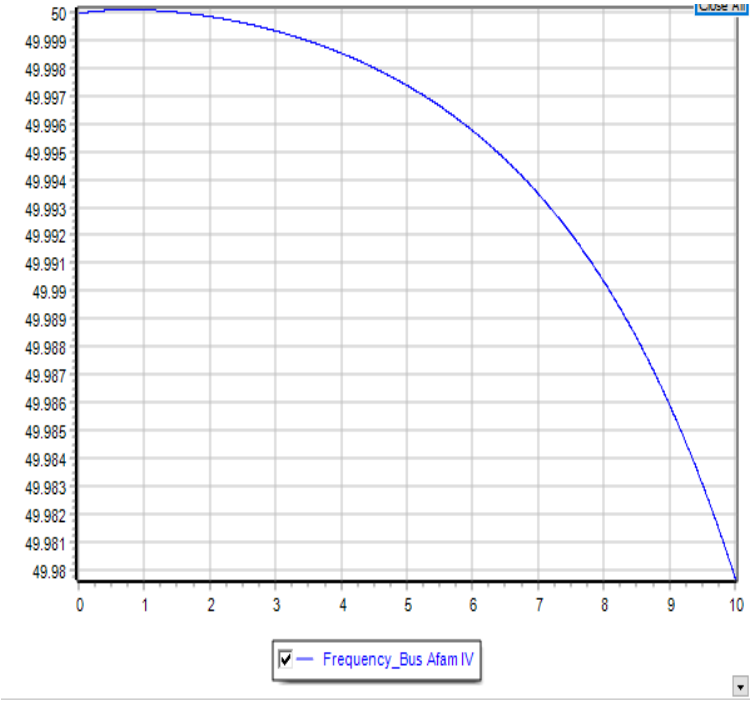

Figure 10: Afam IV $132 \mathrm{kV}$ bus was faulted with 3-phase to ground fault for $150 \mathrm{~ms}$.

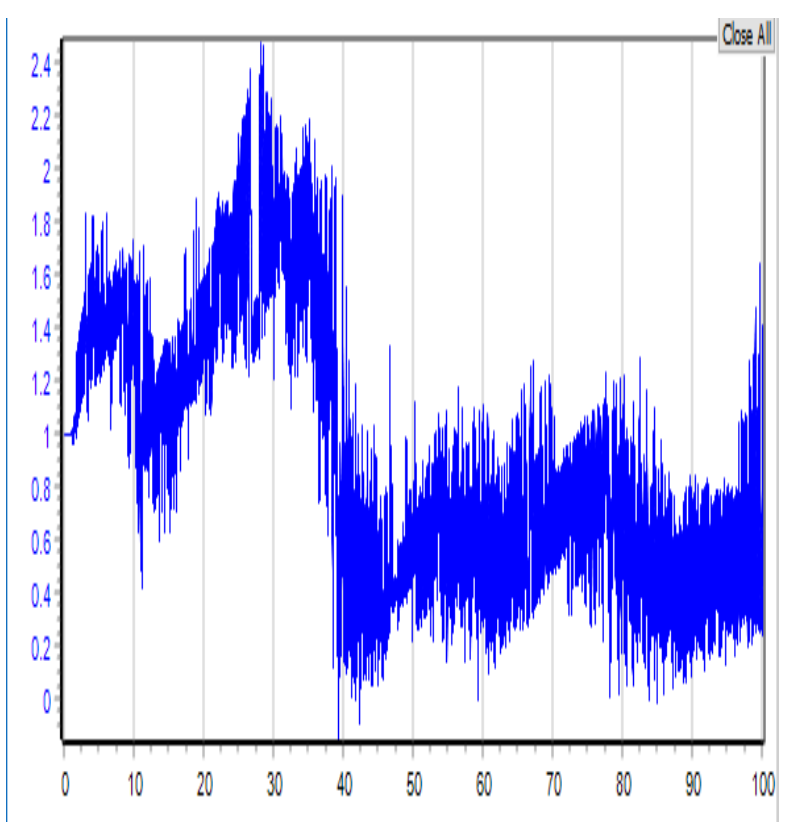

Figure 11: Afam IV $132 \mathrm{kV}$ bus was faulted with 3-phase to ground fault for $150 \mathrm{~ms}$.

\subsection{The Results of Bus and Rotor Angle}

The curves of the angle Figure 9 show how the whole system is maintained for various generators in the system. The angle differences between the different units are minimal. It's also worth noting that there's a uniform oscillation of the angles of bus voltage to a new location within the proper limit, thus testing the system's stability. Other units' angular differences were not too distinct in the process from one another. The rate of many other units, in particular, is fairly consistent with reduced oscillation. 


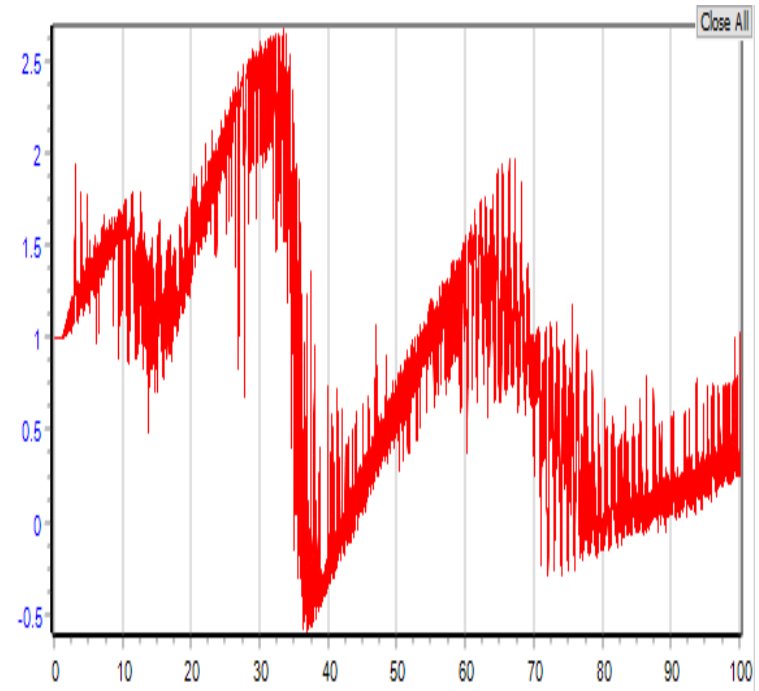

Figure 12: Afam IV 132kV bus and rotor angle was faulted with 3-phase to ground fault for $150 \mathrm{~ms}$.

\subsection{Effect of Substation Splitting on \\ Transient Stability}

After splitting Afam V and Afam III generators, a transient three -Phase fault was added, simulated on the Afam V 132kV bus to look at the impact of splitting on bus frequency and angle. Figure 12 shows the transient stability plot of the bus frequencies on the remaining plants, while the angles of the bus are shown in Figure 13. This demonstrates the structure's stability, when splitting is used, it improves.

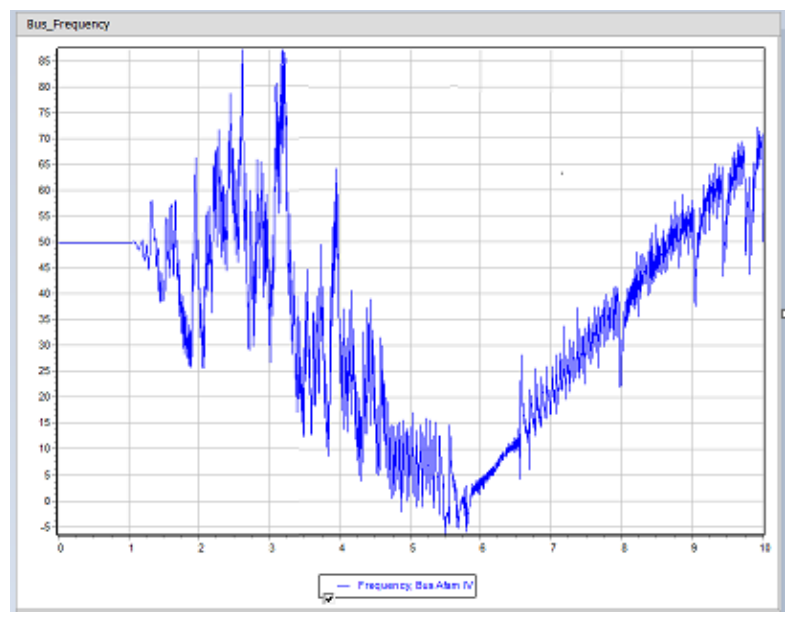

Figure 13: Afam III, IV and V bus frequency and clearing time $100 \mathrm{~ms}$

\subsection{Contingency Analysis}

Only the N-1 criterion was considered to evaluate the contingencies in this work. With one circuit, one generating plant removed, the power flow experiments were replicated. It looked into the impact's effect of the removal on the system. The effect of this elimination of the producing plant was seen in the sharing between the other generating plants of the load it normally supplies, thereby raising their loads. The loading on almost all of the contingency events considered was certain neighboring lines have changed slightly. A significant concern of this removed generator was that the retained Afam IV-Afam $\mathrm{V}$ line had an increase from 85.6 percent to 98.8 percent loading. 
International Journal of Science and Engineering Applications

Volume 10-Issue 11, 163 - 173, 2021, ISSN:- 2319 - 7560

Table 8: Result of the Contingency Analysis

\begin{tabular}{|c|c|c|c|c|c|c|c|}
\hline Number & Gen zone & category & Value & Limit & Percent & Limit & $\begin{array}{l}\text { Nom } \\
\mathrm{kV}\end{array}$ \\
\hline 1 & Afam (IV) & Bus low Volts & 0.7371 & 0.900 & 81.90 & No & 0.900 \\
\hline 2 & Afam (V-) & Bus low Volts & 0.7525 & 0.900 & 83.61 & No & 0.900 \\
\hline 3 & Onne (7) & Bus low Volts & 0.7529 & 0.900 & 83.66 & No & 0.900 \\
\hline 4 & Rivers IPP (4) & Bus low Volts & 0.7529 & 0.900 & 80.16 & No & 0.900 \\
\hline 5 & Afam (IV) & Bus low Volts & 0.6353 & 0.900 & 70.72 & No & 0.900 \\
\hline 6 & Alaoji (6) & Bus low Volts & 0.6545 & 0.900 & 72.78 & No & 0.900 \\
\hline 7 & Onne (7) & Bus low Volts & 0.655 & 0.900 & 72.72 & No & 0.900 \\
\hline 8 & Rivers IPP (4) & Bus low Volts & 0.6191 & 0.900 & 68.79 & No & 0.900 \\
\hline 9 & Afam (IV) & Bus low Volts & 0.5297 & 0.900 & 58.86 & No & 0.900 \\
\hline 10 & Alaoji (6) & Bus low Volts & 0.5489 & 0.900 & 60.05 & No & 0.900 \\
\hline 11 & Onne (7) & Bus low Volts & 0.5489 & 0.900 & 61.05 & No & 0.900 \\
\hline 12 & Rivers IPP (4) & Bus low Volts & 0.5139 & 0.900 & 57.10 & No & 0.900 \\
\hline
\end{tabular}

Table 9: the violations when Afam III is opened

\begin{tabular}{|l|l|l|l|l|l|l|l|}
\hline Number & category & Element & Value & Limit & Percent & Area Name & $\begin{array}{l}\text { Nom } \\
\mathrm{kV}\end{array}$ \\
\hline 1 & Bus low Volts & Rivers IPP (4) & 0.8993 & 0.900 & 99.93 & 1 & 132 \\
\hline 2 & Bus low Volts & Afam (IV) & 0.6923 & 0.900 & 76.92 & 1 & 132 \\
\hline 3 & Bus low Volts & Alaoji (6) & 0.5812 & 0.900 & 64.58 & 1 & 132 \\
\hline 4 & Bus low Volts & Onne (7) & 0.4784 & 0.900 & 53.16 & 1 & 132 \\
\hline
\end{tabular}

\section{CONCLUSION}

The successful studies for evacuation of power from existing generators in Rivers State Nigeria was carried out in this analysis; details of the technical information of the plants were gotten from TCN (Transmission Company of Nigeria). Power flow studies, loading of equipment, short circuit studies, transient stability studies, and N-1 criterion studies were conducted to study the system. The power flow studies described the system's voltage profile. Equipment loading demonstrates the capacity-carrying devices. According to the short circuit studies, several power station buses are flowing from the fault. Stability of the system is maintained after 7.5 cycles of exposure to a transient fault, according to transient stability experiments. The transmission, as observed from the contingency study, capacity in Afam IV cannot withstand N-1 criterion if the three generators fail; thus, there is a requirement to increase the generators' generation capacity to avoid overloading and ultimate generator failure. 


\section{REFERENCES}

[1] Emovon, I., Samuel, O. D., Mgbemena, C. O., and Adeyeri, M. K. (2018). Electric Power generation crisis in Nigeria: A Review of causes and solutions. International Journal of Integrated $\quad$ Engineering, $10(1), \quad 1-20$. https://doi.org/10.30880/ijie.2018.10.01.008

[2] Ohajianya, A. C., Abumere, O. E., Owate, I. O., and Osarolube, E. (2014). Erratic Power Supply in Nigeria: Causes and Solutions. International Journal of Engineering Science Invention, 3(71), 51-55.

[3] Opec

[4] Oyedepo, S. O., Babalola, O. P., Nwanya, S. C., Kilanko, O., Leramo, R. O., Aworinde, A. K., ... Agberegha, O. L. (2018). Towards a Sustainable Electricity Supply in Nigeria: The Role of Decentralized Renewable Energy System. European Journal of Sustainable Development Research, 2(4), 6-8. https://doi.org/10.20897/ejosdr/3908

[5] Oleka, E. U., Ndubisi, S. N., and Ijemaru, G. K. (2016). Electric Power Transmission Enhancement: A Case of Nigerian Electric Power Grid. American Journal of Electrical and Electronic Engineering, 4(1), 33-39. https://doi.org/10.12691/ajeee-4-1-5

[6] World Bank. (2014). Market Information Nigeria Energy Sector. Retrieved 2014, from https://data.worldbank.org/indicator/EG.USE.ELEC.KH.PC

[7] Ralte, R. (2003). Design Of 132 kV Power Evacuation System at Bawktlang Substation in Mizoram. http://hdl.handle.net/123456789/11947

[8] Abdullahi, H., Muhammad, B., and Muhammad, S. (2015). An Optimal Analysis of Power Evacuation in Tiga Hydro Power Plant in Kano State.

[9] Soni, S., S.K. Bajpai, S. K., and Chauhan, R. (2013). Optimum Power Evacuation System Planning of Malwa Thermal Power Station (Stage -II, 2x660MW). International Journal of Advancements in Research \& Technology, 2(12).

[10] Adetona, S., Ugwuagbo, E., Okafor, F., and Akinbulire, T. (2018). Modelling of an Electric Power Grid for New Power Plant Evacuation. FUOYE Journal of Engineering and Technology, 3(2). https://doi.org/10.46792/fuoyejet.v3i2.219

[11] Somolu, F.A. and Okafor, F.N. (2007). Integration and Evacuation Studies for National Integrated Power Projects (NIPP). NIPP Inhouse grid study steam/PHCN.

[12] Abdullahi, H., Muhammad, B. and Muhammad, S. (2015b, September). An Optimal Analysis of Power Evacuation in Tiga Hydro Power Plant in Kano State. 2nd International Conference on Science, New Delhi, India.

[13] Gaya, S, et al. Recent Review on Load/Power Flow Analysis. international Journal of Scientific and Engineering Research, Dec. 2020.

[14] Kumar, Nitesh and Samina Mubeen. "A Review on Load Flow Analysis." Ijird, Nov. 2014.
[15] SURESH, V. (2019). Load Flow Analysis in local microgrid with storage. Przegląd Elektrotechniczny, 1(9), 100 104. https://doi.org/10.15199/48.2019.09.19

[16] Saadat, M. (1978). Application of quasi-Newton method to load flow studies and solution of load flow during threephase fault. Electric Power Systems Research, 1(3), 173-179. https://doi.org/10.1016/0378-7796(78)90021-4

[17] Wu, X., and Mutale, J. (2003). An investigation of network splitting for fault level reduction. Tyndall Centre for Climate Change Research. Published.

[18] Sharma, A., Nirwan, A., and Shekhawat, A. S. (2017). Fault Analysis on Three Phase Transmission Lines and its Detection. International Journal of Advance Research and Innovation, 5(2).

[19] Abduulkareem, A., Awosope, C. O. A., and Awelewa, A. A. (2016). The Use of Three-Phase Fault Analysis for Rating Circuit Breakers on Nigeria 330kv Transmission lines. Journal of Engineering and Applied Sciences, 11(12), 2612-2621.

[20] Anwar, N., Hanif, A. H., Khan, H. F., and Ullah, M. F. (2020). Transient Stability Analysis of the IEEE-9 Bus System under Multiple Contingencies. Engineering, Technology \& Applied Science Research, 10(4), 5925-5932. https://doi.org/10.48084/etasr.3273

[21] Wang, H., and Li, Z. (2019). A Review of Power System Transient Stability Analysis and Assessment. 2019 Prognostics and System Health Management Conference (PHM-Qingdao). Published. qingdao46334.2019.8942834 https://doi.org/10.1109/phm-

[22] Bulat, H., Franković, D., and Vlahinić, S. (2021). Enhanced Contingency Analysis-A Power System Operator $\begin{array}{lll}\text { Tool. } & \text { Energies, } & \text { 14(4), }\end{array}$ https://doi.org/10.3390/en14040923

[23] Alam, M. (2020). Evaluation Of N-1 Contingency Ranking for Security Analysis in Modern Power System. Ethics and Information Technology. Published. https://doi.org/10.26480/etit.02.2020.154.157

[24] Igbinovia, F. O. (2014). A Review of Electrical Energy Systems in Nigeria: Proposal to Increase Consumption. A Review of Electrical Energy Systems in Nigeria: Proposal to Increase Consumption, 1-4. Retrieved from https://www.academia.edu/34444954/A_Review_Of_Electric al Energy Systems In Nigeria Proposal To Increase Cons umption 